\title{
Significance of bacterivory and viral lysis in bottom waters of Franklin Bay, Canadian Arctic, during winter
}

\author{
Llyd E. Wells*, Jody W. Deming \\ School of Oceanography, University of Washington, Seattle, Washington 98195-7940, USA
}

\begin{abstract}
Little information is currently available about water column microbial processes or mortality during Arctic winter. To address this paucity, we used epifluorescence microscopy and dilution experiments to determine the abundance of flagellates, bacteria and virus-like particles (VLP) and the rates of bacterial growth, bacterivory and virus-induced mortality in subzero-temperature bottom waters $(\leq 230 \mathrm{~m}$ ) of Franklin Bay during February and March 2004, when ice-covered surface waters were highly oligotrophic (maximum chlorophyll a value of $0.09 \mathrm{\mu g} \mathrm{l}^{-1}$ ). We focused on bottom waters due to the possible importance of sediment resuspension as a source of organic matter. While flagellates were present at low densities $\left(1.5\right.$ to $\left.3.1 \times 10^{2} \mathrm{ml}^{-1}\right)$, bacterial concentrations resembled those from other seasons in the region and increased over the $5 \mathrm{wk}$ sampling period, from $1.4 \times 10^{5}$ to $3.0 \times$ $10^{5} \mathrm{ml}^{-1}$. VLPs were typically an order of magnitude more abundant than bacteria (range of 1.4 to $4.5 \times 10^{6} \mathrm{VLP} \mathrm{ml}^{-1}$ ) and, like the fraction of particle-associated bacteria (but not total bacteria), correlated with particulate organic carbon concentration $\left(r_{s}=0.82, p<0.04, n=7\right)$. Grazing rates, whether measured in dilution experiments or calculated from flagellate abundance, were low or undetectable (maximum of $-0.004 \mathrm{~h}^{-1}$ ). Of 3 parallel experiments, 2 yielded substantial virus-induced mortality $\left(-0.006\right.$ to $\left.-0.015 \mathrm{~h}^{-1}\right)$, comparable to or exceeding the intrinsic bacterial growth rate $\left(0.010 \mathrm{~h}^{-1}\right.$ in both experiments) and suggesting viruses were the more important agents of bacterial mortality under these conditions. Using a viral reduction approach, VLP production measured in the water column or ice-moored sediment traps was commonly low $\left(0.3\right.$ to $\left.7.7 \times 10^{4} \mathrm{VLP} \mathrm{m}^{-1} \mathrm{~h}^{-1}\right)$ or undetectable, highly variable among replicates and, when measurable, implied viral turnover times between 0.9 and $12 \mathrm{~d}$. In general, our results show that, despite the oligotrophy of Arctic winter, bottom water bacterial communities can remain active and subject to viral predation.
\end{abstract}

KEY WORDS: Virus $\cdot$ VLP $\cdot$ Lysis $\cdot$ Bacterivory $\cdot$ Arctic $\cdot$ Winter $\cdot$ Franklin Bay $\cdot$ Particles

\section{INTRODUCTION}

Viruses are abundant throughout the ocean, including the cold waters at depth (e.g. Hara et al. 1996) and high latitudes (Steward et al. 1996, Yager et al. 2001, Guixa-Boixereu et al. 2002), and commonly account for 10 to $40 \%$ of bacterial losses (see Table 4 in Weinbauer et al. 2002), sometimes comparable to grazers (e.g. Fuhrman \& Noble 1995). The relative contribution of viruses and grazers to bacterial mortality has important consequences for the processing and transfer of organic matter in the ocean. Specifically, by converting bacteria (thought to be the predominant hosts of viruses in the ocean; Cochlan et al. 1993, Wommack \& Colwell 2000) into dissolved organic matter (DOM), viral lysis may short-circuit energy transfer to higher trophic levels and instead recycle organic matter within the bacterial pool, possibly enhancing bacterial production and respiration (e.g. Fuhrman \& Suttle 1993, but see Eissler et al. 2003). In terms of mesozooplankton production, this shunt has been argued to be relatively unimportant, except under oligotrophic con- 
ditions with high (>50\%) virus-induced mortality (Murray \& Eldridge 1994). Yet such conditions favor lower concentrations of bacteria and viruses (compared to eutrophic circumstances, e.g. Cochlan et al. 1993, Hewson et al. 2001), correspondingly lower encounter rates (Murray \& Jackson 1992), reduced virus production and/or virus-induced mortality (Steward et al. 1992, 1996, Weinbauer \& Peduzzi 1995, Guixa-Boixereu et al. 2002) and, perhaps, a greater likelihood of lysogeny (Weinbauer \& Suttle 1999, Weinbauer et al. 2003).

Viruses may exert a more subtle influence by generating a relatively labile lysate which, though a small component of DOM, may nonetheless be an important source of organic matter to other microorganisms (Middelboe et al. 1996, Gobler et al. 1997), especially under oligotrophic conditions (Noble \& Fuhrman 1999). In fact, a laboratory study has shown that viral lysate can solely support bacterial growth (Middelboe et al. 2003). Viral lysis could thus help to maintain an active and perhaps more diverse bacterial assemblage, not only 'killing the winner' (Wommack et al. 1999) but 'feeding the survivors,' during periods of pronounced oligotrophy. Similarly, lysogenic interactions may also have important ecological consequences, given laboratory data suggesting that lysogenic bacteria have a competitive advantage over nonlysogenized strains, specifically under conditions of carbon limitation (Edlin et al. 1977, Lin et al. 1977). Thus, the ecological significance of viruses during oligotrophic periods may be more nuanced than their effect on the transfer of organic matter to higher trophic levels.

The oligotrophic conditions prevailing in the Arctic water column during winter present an attractive endmember ecological system in which to consider the importance of viruses. Low light levels and sea ice typically $>1 \mathrm{~m}$ in thickness limit significant production by marine phytoplankton (Rysgaard et al. 1999). This constraint, as well as the difficulties of winter-time sampling, presumably accounts for the paucity of studies of under-ice pelagic processes during this season. The limited available data support a picture of a relatively inactive ecosystem: chlorophyll a (chl a) concentrations and zooplankton biomass are commonly at or below detection limits (e.g. Rysgaard et al. 1999, Anderson \& Rivkin 2001, Levinsen \& Nielsen 2002, Melnikov et al. 2002), while bacterial abundance, specific growth rate and/or metabolic activity are low (and respiration percentage high) compared to summer values (Griffiths et al. 1978, Anderson \& Rivkin 2001; also observed in the Antarctic: Tien et al. 1992, Helmke \& Weyland 1995). The microbial food web may nonetheless remain dynamic, with microzooplankton grazing most or all of the bacterial secondary production (Anderson \& Rivkin 2001). Since inputs from photosynthetic production are low, alternative modes of primary production (for example, nitrification), greater utilization of allochthonous material (Daniel et al. 2005) and/or enhanced recycling may be favored. In particular, the ecological significance of resuspended, sediment-derived organic matter may increase during winter, as has been observed in a freshwater system (Cotner et al. 2000). Correspondingly, particle-attached bacteria may also become more important, accounting for a larger fraction of bacterial activity or secondary production than expected based on their numerical abundance (Griffith et al. 1994, Junge et al. 2004).

In the work reported here, we examined the significance of grazers and viruses to bacterial mortality during the coldest 5 wk period of Arctic winter, focusing on bottom waters, due to the possible importance of sediment resuspension as a source of organic material. The prevailing oligotrophic conditions during winter were expected to favor an ecosystem in which planktonic metabolic activity was dominated by microorganisms (Cotner et al. 2000) and in which the impact of viruses might be accentuated (Murray \& Eldridge 1994). Our suite of measurements included rates of virus-like particle (VLP) production, virus-induced mortality, grazing and bacterial growth, as well as initial (in situ) concentrations of particulate matter and microorganisms. Given the importance of bacteria associated with particles to bacterial activity in Arctic waters (Yager et al. 2001, Huston \& Deming 2002, Garneau et al. 2006), we also attempted to estimate the contributions of free-living and particle-associated bacteria (PAB) to VLP production using a sizefractionation approach.

\section{MATERIALS AND METHODS}

Field site and sampling. Sampling was conducted every 5 to $7 \mathrm{~d}$ from the NGCC 'Amundsen' between 22 February (pilot sample) and $23 \mathrm{March}$, the coldest winter period of 2004 (air temperatures commonly below $-30^{\circ} \mathrm{C}$ ). During this time, the 'Amundsen' was frozen into the first year ice of Franklin Bay $\left(70.0^{\circ} \mathrm{N}\right.$, $126.3^{\circ} \mathrm{W}$ ), thus serving as a stationary field laboratory over a water column of $\sim 230 \mathrm{~m}$ depth. For 3 experiments (Expts 1-SW, 2-SW and 4-SW), 50 l of water were collected within $2 \mathrm{~m}$ of the bottom in Niskin bottles deployed by rosette from the ship's Moon Pool. Bottom water temperatures consistently registered ca. $-0.5^{\circ} \mathrm{C}$ during the study. For 2 experiments (Expts 3SW and 5-SW) and to fit experimental work into the overall expedition logistics, a bottom-tripped Niskin bottle (rather than rosette) was deployed repeatedly over $\sim 30$ min until $\sim 40 \mathrm{l}$ of water from roughly $0.5 \mathrm{~m}$ 
above the bottom were recovered, either from the Moon Pool (Expt 5-SW) or from $115 \mathrm{~m}$ water depth at Angaguk (Expt 3-SW), a field site $18 \mathrm{~km}$ west of the ship $\left(70.0^{\circ} \mathrm{N}, 126.7^{\circ} \mathrm{W}\right)$ near the mouth of the Horton River. In all cases, Niskin water was screened through a Nitex mesh (209 $\mu \mathrm{m}$ pore size) to remove large grazers and consolidated in carboys. Processing began immediately in a temperature-controlled shipboard laboratory set at $0^{\circ} \mathrm{C}$, except for the water from Angaguk, which required $2.5 \mathrm{~h}$ for over-ice transit to the ship, during which time it warmed $<3^{\circ} \mathrm{C}$.

In addition to sampling bottom seawater, we took advantage of access to an ice-moored sediment trap (IST; total volume $\sim 6$ l) to estimate virus production by bacteria associated with sinking material. The IST was deployed on 2 occasions (Expt 4-IST and Expt 5-IST) for 23 to $24 \mathrm{~h}$ at a depth of $\sim 210 \mathrm{~m}$ at Takatuk, a field site $1.8 \mathrm{~km}$ east of the ship. In each case, the trap was filled with $0.2 \mu \mathrm{m}$ filtered seawater collected at a comparable depth prior to deployment. Upon recovery, the samples were returned as quickly as possible to the $0^{\circ} \mathrm{C}$ laboratory for immediate processing; in the case of the sample for Expt 5-IST, some freezing occurred in transit, resulting in a temporary $(\sim 1 \mathrm{~cm})$ surface slush of ice crystals. In the laboratory, the trap contents were transferred to a carboy, mixed gently, Nitex-screened and processed as described below, with adjustments for the limited volume. All containers (carboys and bottles) used in this work were acid-washed and rinsed multiple times with distilled water; a final series of rinses was performed with the seawater sample itself immediately before the experiment.

Measurements of initial concentrations of study variables. Following recovery and Nitex-screening of water shipboard, samples were taken to determine the initial (in situ) concentrations of bacteria, VLP, PAB, particles and particulate organic carbon (POC) and nitrogen (PON). For bacteria, VLP and particles, $10 \mathrm{ml}$ subsamples were fixed with $37 \% \quad 0.2 \mu \mathrm{m}$ filtered formaldehyde (final concentration 1.5\%) and stored cold in $\mathrm{a}-1^{\circ} \mathrm{C}$ incubator. Slides were prepared as soon as possible (and always within a few hours), using an approach modified from Noble \& Fuhrman (1998). Briefly, the fixed samples were filtered under low vacuum onto $25 \mathrm{~mm}, 0.02 \mu \mathrm{m}$ Anodisc filters (Whatman), dried by gently brushing the underside against a kimwipe for $2 \mathrm{~min}$, stained in the dark for 15 to $30 \mathrm{~min}$ with $100 \mu \mathrm{l}$ of $0.1 \%$ SYBR Gold (Molecular Probes), and dried as before. The filters were then mounted on a glass slide with $30 \mu \mathrm{l}$ of medium consisting of $50 \%$ glycerol, $50 \%$ phosphate-buffered saline and $0.5 \%$ ascorbic acid. Once prepared, slides were stored frozen (at $-20^{\circ} \mathrm{C}$ ) until analysis within $4 \mathrm{mo}$ on a Zeiss Universal microscope at $1563 \times$ magnification, counting a minimum of 20 fields.
For estimation of $\mathrm{PAB}, 30$ to $35 \mathrm{ml}$ of the fixed samples were filtered through a $25 \mathrm{~mm}, 3.0 \mu \mathrm{m}$ polycarbonate filter and a smaller volume through a similar but $0.22 \mu \mathrm{m}$ black polycarbonate filter. Each filter was placed on a glass slide and stained with a drop of Vectashield mounting medium (Vector Laboratories) containing $1.5 \mu \mathrm{g} \mathrm{ml}^{-1}$ of the DNA stain 4, 6-diamidino-2phenylindole (DAPI). The slides were then stored frozen $\left(-20^{\circ} \mathrm{C}\right)$ until microscopic examination as above. Later, land-based analysis found that after this period of frozen storage, the DAPI-Vectashield produced a diffuse background on black polycarbonate filters that obscured stained cells. This problem was remedied by gently removing the cover slip, bleaching the filter with $70 \%$ ethanol on a filter box, adding a small drop of fresh DAPI-Vectashield, and re-making the slide using the same slide and cover slip as before to minimize cell losses. The percent PAB was determined as the concentration of bacteria retained on the $3.0 \mu \mathrm{m}$ filter divided by the concentration on the $0.22 \mu \mathrm{m}$ filter $(\times 100)$. Bacteria retained on the $3.0 \mu \mathrm{m}$ filter were sometimes not visibly associated with particles; given possible attachment to transparent particles, such cells were counted.

For POC and PON determinations, triplicate $100 \mathrm{ml}$ samples were gently filtered onto muffled $25 \mathrm{~mm} \mathrm{GF/F}$ filters and stored frozen in muffled scintillation vials until analysis at the University of Washington, as described in Wells \& Deming (2003). Briefly, samples were incubated overnight at $60^{\circ} \mathrm{C}$, exposed to $\mathrm{HCl}$ vapors to remove inorganic carbon and measured on a CHN analyzer (Model CE440, Leeman Laboratories), first correcting for blanks.

Measurements of VLP production. VLP production was measured using the viral dilution approach of Wilhelm et al. (2002). To distinguish these experiments from the dilution experiments described below, however, we refer to them as 'viral reduction experiments.' A volume of $\sim 10$ l of seawater was ultrafiltered through a $30 \mathrm{kDa}$ cutoff, low-protein-binding, regenerated cellulose membrane (Prep/Scale TFF cartridge, nominal $0.23 \mathrm{~m}^{2}$ filter area; Millipore) to create a VLP-free ultrafiltrate (UF) for use as a diluent. For every experiment, samples of fixed UF were examined by SYBRstaining and microscopy for VLP, which were seldom detected and always negligible $\left(\leq 300 \mathrm{ml}^{-1}\right)$. A sample volume of 31 of (unfiltered) seawater was then concentrated $\sim 5$-fold (by volume) over a $47 \mathrm{~mm}, 0.2 \mu \mathrm{m}$ polycarbonate filter (retaining bacteria but passing VLP) at low pressure $(<258 \mathrm{mmHg})$, using a transfer pipette to keep bacteria in suspension and adding UF to maintain volume. By reducing VLP (but not bacterial) concentrations, this procedure was intended to favor measurement of VLP production due to infections prior to the start of the experiment, as well as to reduce back- 
ground VLP concentration (the better to detect changes). Following viral reduction, water was subdivided into $500 \mathrm{ml}$ batches incubated in triplicate and in the dark at $-0.5^{\circ} \mathrm{C}$ in $500 \mathrm{ml}$ polycarbonate bottles. Subsamples $(10 \mathrm{ml})$ taken at $t=0$ were fixed and stained with SYBR Gold as above. Additional time points were typically taken and prepared as above after 5, 10, 20 and 42 h; in Expts 2-SW and 3-SW, extra time points were taken at 3 and $30 \mathrm{~h}$ as well.

For a subset of 4 experiments (Table 1) directed at examining the importance of $\mathrm{PAB}$ to viral production, seawater samples were first filtered by gravity through an acid-cleaned, distilled and seawater-rinsed, $3.0 \mu \mathrm{m}$ Versapor membrane capsule filter (Pall Gelman) to remove particles and associated bacteria. This water was then virally reduced, dispensed and incubated as described. Here, we refer to these experiments as the 'filtered' VLP production experiments, compared to the standard 'unfiltered' experiments above.

In all cases, to maximize the objectivity of counts, slides from a given experiment were randomized and counted without knowing sample identity (i.e. replicate, treatment, or time point), but within the same general period of time (to minimize differential losses during storage). Production rates were then calculated as the slope of the linear regression of VLP abundance against time and, subsequently, corrected for loss of bacteria during viral reduction, as in Wilhelm et al. (2002).

Measurements of grazing and virus-induced mortality. Grazing and virus-induced mortality were estimated for subsets of 4 and 3 experiments, respectively (Table 1), using the dilution technique of Landry \& Hassett (1982) applied to bacterivory (Tremaine \& Mills 1987) and modified to determine virus-induced mortality according to Evans et al. (2003). For grazing measurements, 41 of seawater were gravity-filtered through an acid-cleaned, distilled and seawaterrinsed, $0.2 \mu \mathrm{m}$ Versapor membrane capsule filter (Pall Gelman). Whole (unfiltered) seawater was then diluted with filtered seawater 1:10, 1:5, 1:2, or left undiluted (1:0). All treatments were contained in $500 \mathrm{ml}$ polypropylene bottles incubated in duplicate at $-0.5^{\circ} \mathrm{C}$. To examine the possibility that grazing was tightly coupled to actively growing bacteria (for example, particle-associated bacteria), additional duplicate 1:0 and 1:10 incubations were amended with $0.01 \%$ yeast extract (final conc.) in order to stimulate freeliving bacterial growth. Subsamples $(10 \mathrm{ml})$ were taken at the start of the experiment $(t=0)$, after approximately $30 \mathrm{~h}$, and at 55 (Expt 3-SW) or $64 \mathrm{~h}$ (Expts 5-SW and 5-IST; no third time point was subsampled for Expt 1-SW). Each subsample was fixed with $1 \%$ (final conc.) electron microscopy-grade glutaraldehyde, filtered onto $0.2 \mu \mathrm{m}$ polycarbonate filters and stained with DAPI as above. Prepared slides were then stored frozen until microscopic examination as before. Fixation with glutaraldehyde permitted estimation of flagellate (though not ciliate) abundance, which, assuming a clearance rate of $10 \mathrm{nl} \mathrm{h}^{-1}$ (as in prior Arctic work; Steward et al. 1996), enabled a second measure of grazing. Flagellates were counted only in the undiluted treatments at the initial time point.

Experiments to measure virus-induced mortality were prepared like the grazing dilution experiments, except that UF was used instead of $0.22 \mu \mathrm{m}$ filtrate to dilute whole seawater (thereby reducing the probability of encounter between VLP and cells, as dilution with $0.2 \mu \mathrm{m}$ filtrate does between grazers and cells; Evans et al. 2003). Three levels of dilution were evaluated in duplicate: 1:10, 1:2 and 1:0. Subsamples $(10 \mathrm{ml})$ were taken from each dilution at $t=0$ and $41 \mathrm{~h}($ Expt 1 -

Table 1. Sample locations, experimental designations, dates and treatments. The $0.2 \mu \mathrm{m}$ and virus-like particle (VLP)-free dilution experiments were used to determine grazing and virus-induced mortality rates, respectively. Seawater (SW) samples were taken within $\sim 2.0 \mathrm{~m}$ of the bottom ( $\sim .5 \mathrm{~m}$ for bottom-tripped Niskin samples). Ice-moored sediment traps (IST) were deployed at a depth of $210 \mathrm{~m}$ for $\sim 24 \mathrm{~h}$. X: experiment performed; nd: not determined

\begin{tabular}{|c|c|c|c|c|c|c|c|}
\hline \multirow{2}{*}{$\begin{array}{l}\text { Sample } \\
\text { location }\end{array}$} & \multirow{2}{*}{$\begin{array}{l}\text { Sample depth } \\
(\mathrm{m})\end{array}$} & \multirow{2}{*}{$\begin{array}{l}\text { Sample } \\
\text { date }\end{array}$} & \multirow[t]{2}{*}{ Expt } & \multicolumn{2}{|c|}{ VLP production } & \multicolumn{2}{|c|}{ Dilution experiments } \\
\hline & & & & Unfiltered & Filtered & $0.2 \mu \mathrm{m}$ & VLP-free \\
\hline Moon Pool & 228 & $28 \mathrm{Feb}$ & 1-SW & $\mathrm{X}$ & $X$ & $X$ & $X$ \\
\hline Moon Pool & 228 & 5 Mar & 2-SW & $X$ & nd & nd & nd \\
\hline Angaguk $^{a}$ & 114 & $12 \mathrm{Mar}$ & $3-\mathrm{SW}^{\mathrm{b}}$ & $X$ & $\mathrm{X}$ & $\mathrm{X}$ & $X$ \\
\hline Moon Pool & 228 & 17 Mar & 4-SW & $\mathrm{X}$ & nd & nd & nd \\
\hline Takatuk $^{\mathrm{c}}$ & 210 & 17-18 Mar & 4-IST & $X$ & nd & nd & nd \\
\hline Moon Pool & 229 & 23 Mar & $5-\mathrm{SW}^{\mathrm{b}}$ & $\mathrm{nd}^{\mathrm{d}}$ & $\mathrm{X}$ & $\mathrm{X}$ & $\mathrm{X}$ \\
\hline Takatuk $^{\mathrm{c}}$ & 210 & 22-23 Mar & 5-IST & $\mathrm{X}$ & $\mathrm{X}$ & $X$ & nd \\
\hline \multicolumn{8}{|c|}{$\begin{array}{l}\text { a A field site near the mouth of the Horton River, } 18 \mathrm{~km} \text { west of the ship }\left(70.0^{\circ} \mathrm{N}, 126.7^{\circ} \mathrm{W}\right) \\
{ }^{\mathrm{b}} \text { Water collected by bottom-tripped Niskin } \\
{ }^{\mathrm{c}} \text { A field site } 1.8 \mathrm{~km} \text { east of the ship }\end{array}$} \\
\hline
\end{tabular}


Table 2. Initial (in situ) particulate and microbial variables. The indicated error value is standard error of the mean; nd: not determined; POC: particulate organic carbon; PON: particulate organic nitrogen; PAB: particle-associated bacteria; VLP: viruslike particles; VBR: VLP-to-bacteria ratios

\begin{tabular}{|c|c|c|c|c|c|c|c|c|c|}
\hline Expt & $\begin{array}{l}\text { Date } \\
(2004)\end{array}$ & $\begin{array}{c}\text { POC } \\
\left(\mu \mathrm{g} \mathrm{l}^{-1}\right)\end{array}$ & $\begin{array}{c}\text { PON } \\
\left(\mu \mathrm{g} \mathrm{l}^{-1}\right)\end{array}$ & $\begin{array}{c}\text { Particles } \\
\left(\times 10^{4} \mathrm{ml}^{-1}\right)\end{array}$ & $\begin{array}{c}\text { PAB } \\
(\%)\end{array}$ & $\begin{array}{c}\text { Bacteria } \\
\left(\times 10^{5} \mathrm{ml}^{-1}\right)\end{array}$ & $\begin{array}{c}\text { VLP } \\
\left(\times 10^{6} \mathrm{ml}^{-1}\right)\end{array}$ & VBR & $\begin{array}{l}\text { Flagellates } \\
\left(\times 10^{2} \mathrm{ml}^{-1}\right)\end{array}$ \\
\hline Pilot $^{\mathrm{a}}$ & 22 Feb & 53 & 38 & nd & 3 & 1.4 & 1.4 & 10 & 1.5 \\
\hline 1-SW & $28 \mathrm{Feb}$ & $68 \pm 24$ & $32 \pm 6$ & 0.76 & 3 & 1.8 & 1.4 & 7.6 & 2.3 \\
\hline 2-SW & 5 Mar & $106 \pm 44$ & $28 \pm 5$ & 6.8 & 8 & 2.0 & 1.6 & 8.1 & nd \\
\hline 3-SW & 12 Mar & $83 \pm 14$ & $30 \pm 1$ & 17 & 9 & 1.2 & 3.3 & 27 & 2.3 \\
\hline 4-SW & 17 Mar & $80 \pm 35$ & $28 \pm 4$ & 7.9 & 2 & 2.4 & 3.2 & 14 & nd \\
\hline 4 -IST & 17-18 Mar & $194 \pm 46$ & $50 \pm 16$ & 15 & 6 & 1.4 & 4.5 & 32 & nd \\
\hline 5-SW & 23 Mar & $770 \pm 117$ & $115 \pm 9$ & nd & 11 & $3.0^{\mathrm{b}}$ & nd & nd & 2.7 \\
\hline 5-IST & 22-23 Mar & $319 \pm 35$ & $75 \pm 4$ & 28 & 10 & 2.8 & 4.0 & 14 & 3.1 \\
\hline
\end{tabular}

SW), $t=0,30$ and $55 \mathrm{~h}$ (Expt 3-SW) and $t=0,42.5$ and 65.5 (Expt 5-SW). Each subsample was fixed with 1.5\% (final concentration) $0.2 \mu \mathrm{m}$ filtered formaldehyde and then processed, stored and analyzed as in the grazing experiments.

For both the grazing and virus-induced mortality dilution experiments, an empirical (bacteria-based) dilution factor (DF) was calculated (from the $t=0$ bacterial abundances in each dilution, divided by the mean $t=0$ bacterial abundance in untreated seawater) and used instead of the volumetric DF. Assuming exponential growth, apparent growth rate was calculated as the linear regression against time of the natural log of bacterial abundance in each dilution. Apparent growth rates determined in this way for each duplicate were then plotted against the empirically determined seawater fraction to estimate both the intrinsic (in situ) bacterial growth rate (the $y$-intercept) and, from the slope, mortality due to grazing $\left(m_{\mathrm{g}}\right.$ from the $0.2 \mu \mathrm{m}$ filtered dilution experiments) or due to grazing and viruses $\left(m_{\mathrm{g}}+m_{\mathrm{v}}\right.$ from the VLP-free dilution experiments). The difference between the 2 slopes thus provides an estimate of mortality due to viruses alone $\left(m_{\mathrm{v}}=\left[m_{\mathrm{g}}+m_{\mathrm{v}}\right]-m_{\mathrm{g}}\right)$. A second estimate of virusinduced mortality $\left(m_{\mathrm{v}}{ }^{*}\right)$ was derived from the difference in $y$-intercepts (i.e. intrinsic bacterial growth rates) of $0.2 \mu \mathrm{m}$ filtered $\left(\mu_{\mathrm{g}}\right)$ and VLP-free dilution experiments $\left(\mu_{\mathrm{v}}\right)$, since in the former the intrinsic bacterial growth rate implicitly includes mortality due to viruses, while in the latter it does not (e.g. $m_{\mathrm{v}}{ }^{*}=\mu_{\mathrm{g}}-\mu_{\mathrm{v}}$; Evans et al. 2003). Also, for this reason, the true in situ bacterial growth rate was taken to be $\mu_{\mathrm{v}}$. Finally, in addition to solving for $m_{\mathrm{v}}$ by subtracting the slope of the $0.2 \mu \mathrm{m}$ filtered dilutions $\left(m_{\mathrm{g}}\right)$ from the slope of the VLP-free dilutions $\left(m_{\mathrm{g}}+m_{\mathrm{V}}\right)$, we also used $m_{\mathrm{V}}{ }^{*}$ to solve for $m_{\mathrm{g}}$, designating this second estimate of $m_{\mathrm{g}}$ as $m_{\mathrm{g}}{ }^{*}$, where $m_{\mathrm{g}}{ }^{*}=\left(m_{\mathrm{g}}+m_{\mathrm{v}}\right)-m_{\mathrm{v}}{ }^{*}$.

\section{RESULTS}

\section{Water column characteristics}

The winter water column was covered by ice of 1 to $2 \mathrm{~m}$ in thickness throughout the sampling period. As light levels increased, so did surface-water chl a concentrations (by approximately 6-fold), though their overall low values (maximum of only $0.09 \mathrm{\mu g} \mathrm{l}^{-1}$ in the upper $25 \mathrm{~m}$; S. Demers pers. comm.) were consistent with oligotrophy. POC concentrations in the bottom waters ranged from 53 to $770 \mu \mathrm{g} \mathrm{l}^{-1}$ (Table 2), the highest value coming from the sample for Expt 5-SW. PON concentrations were less variable, ranging from 28 to $115 \mu \mathrm{g} \mathrm{l}^{-1}$ (Table 2). POC and PON in the trap samples were typically greater than in the bottom water samples, except for the particle-rich water of Expt 5-SW (Table 2). Bottom water particle concentrations (determined microscopically) varied between $7.6 \times 10^{3}$ and $1.7 \times 10^{5} \mathrm{ml}^{-1}$ and were usually lower than in the 2 IST experiments $\left(1.5\right.$ to $2.8 \times 10^{5} \mathrm{ml}^{-1}$ ).

\section{Abundance of bacteria, VLP and flagellates}

Initial bacterial concentrations determined by staining with SYBR (for simultaneous VLP enumeration) and by DAPI (the $0.2 \mu \mathrm{m}$ filters prepared to determine $\mathrm{PAB})$ correlated with one another $\left(\mathrm{r}_{\mathrm{s}}=0.85, \mathrm{p}<0.05\right.$, $\mathrm{n}=6$ ), with a slope of 0.9 (DAPI counts being on average higher). The additional sample manipulation associated with ethanol rinses of DAPI slides thus did not result in significant cell losses. For the sake of consistency with the VLP counts, bacterial concentrations reported here were derived by SYBR staining, except for Expt 5-SW. In that sample, SYBR counts (of bacteria or VLP) were not possible due to extremely large con- 

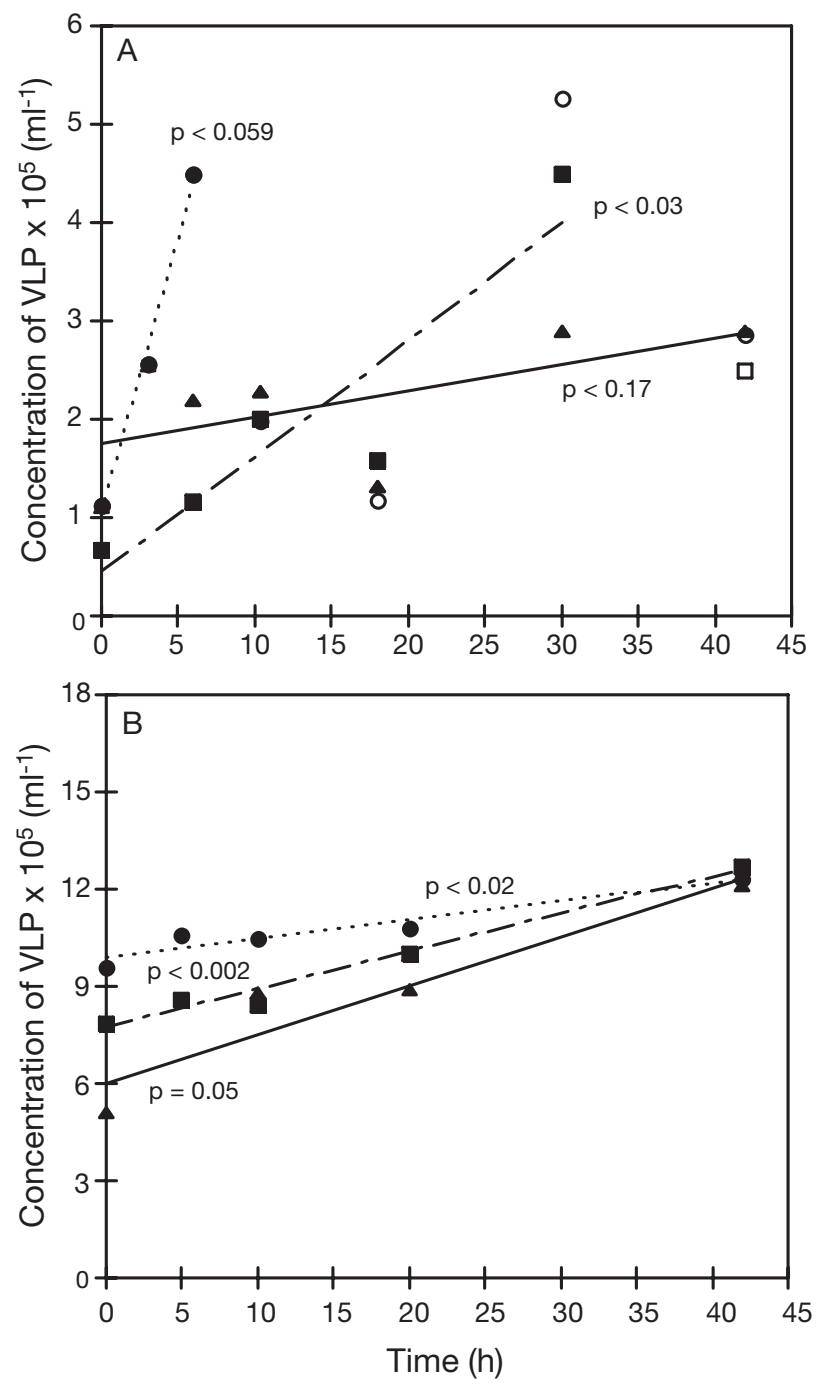

Fig. 1. Virus-like particle (VLP) dynamics in unfiltered incubations of (A) Expt 2-SW and (B) Expt 5-IST (3 replicates designated as follows: $\boldsymbol{\Lambda},-; \boldsymbol{\bullet}, \ldots . . ; \mathbf{\square},---)$. Closed symbols indicate data used for the regressions (lines) of each replicate, with the significance level (p) indicated; open symbols in Panel A show data from later time points not used in the corresponding regression. Note that the ordinate scales of Panels A and B differ

centrations of particles (also not countable) causing high background fluorescence and occlusion of the field of view. DAPI slides on which bacteria were countable are reported instead, though the values are likely underestimates.

Initial bacterial concentrations varied over a range of 1.2 to $3.0 \times 10^{5} \mathrm{ml}^{-1}$ (Table 2 ). Those in bottom waters sampled from the Moon Pool showed a significant linear increase with calendar day $(\mathrm{p}<0.004, \mathrm{n}=5$; if the particle-rich 5-SW sample is excluded, $\mathrm{p}<0.02, \mathrm{n}=4$ ). Bacterial abundance did not differ markedly between seawater and trap samples. The percentage of PAB ranged from 2 to $11 \%$ of total bacteria and, unlike total bacteria, correlated with POC concentration $\left(r_{s}=0.83\right.$, $\mathrm{p}<0.02)$.

The range of VLP concentrations was 1.4 to $4.5 \times 10^{6}$ $\mathrm{ml}^{-1}$ (Table 2), with highest concentrations in the trap samples (which include the initial, unmeasured VLP load in the $0.2 \mu \mathrm{m}$ filtered bottom water used to fill the traps). VLP-to-bacteria ratios (VBR) were generally high (median of 14, or 10 if IST are excluded; range of 7.6 to 32 ). Like the percentage of PAB, VLP correlated significantly with POC concentration $\left(\mathrm{r}_{\mathrm{s}}=0.82\right.$, $\mathrm{p}<$ $0.04, \mathrm{n}=7$ ). In addition, they correlated with sampling time or calendar day of the year $\left(\mathrm{r}_{\mathrm{s}}=0.89, \mathrm{p}<0.02, \mathrm{n}=\right.$ 7; Table 2), while tending to increase with particle concentration $\left(\mathrm{r}_{\mathrm{s}}=0.83, \mathrm{p}<0.06, \mathrm{n}=6\right)$.

Flagellates were observed in all samples at low densities $\left(1.5\right.$ to $3.1 \times 10^{2} \mathrm{ml}^{-1}$, counting 100 fields per slide). Although no correlations of flagellate abundance with other measured variables were significant, they tended to increase with calendar day of the year and with POC and the percentage of PAB $\left(\mathrm{r}_{\mathrm{s}}=0.875\right.$, $\mathrm{p}<0.09, \mathrm{n}=5$ for each).

\section{VLP production}

Following reduction, VLP concentrations were $21 \pm$ $4 \%$ (standard error of the mean) of initial values (in good agreement with the volumetric dilution), while bacterial concentrations remained high $(65 \pm 7 \%$ of initial values). VLP dynamics differed considerably among independent replicates (the most extreme example is shown in Fig. 1A). Significant $(p \leq 0.05)$ or marginally insignificant $(p<0.06)$ production rates, ranging from 0.7 to $20 \times 10^{4} \mathrm{VLP} \mathrm{ml}^{-1} \mathrm{~h}^{-1}$, were determined in 7 (of 30) cases, while in 2 cases, decay rates of -0.3 and $-1.6 \times 10^{4} \mathrm{VLP} \mathrm{ml}^{-1} \mathrm{~h}^{-1}$ were measured (Table 3 ). In only 1 experiment (5-IST) did all 3 replicates yield positive slopes significantly different from zero (Fig. 1B). Filtered incubations resulted in a significant production rate in only 1 case (of 12), compared to in 6 cases (of 18) in unfiltered incubations (with net declines in an additional 2; Table 3). Overall, VLP production or decay rates averaged across replicates were low, varying between -0.5 and $7.7 \times 10^{4} \mathrm{VLP} \mathrm{ml}^{-1} \mathrm{~h}^{-1}$ and, when calculable, implied viral turnover times in unfiltered experiments of 0.9 (Expt 2-SW), 11.8 (Expt 3-SW) and 6.3 d (Expt 5-IST) (Table 4).

\section{Grazing and virus-induced mortality}

In unamended treatments of the $0.2 \mu \mathrm{m}$ filtered dilution experiments, no grazing rates (i.e. slopes or $m_{\mathrm{g}}$ ) significantly different from zero were detected 
Table 3. Significant $(\mathrm{p}<0.05)$ VLP production rates in triplicate $(A, B, C)$ incubations and corrected for bacterial losses during viral reduction. Linear regressions with marginally significant $(p=0.05)$ or marginally insignificant $(\mathrm{p}<0.06)$ slopes are marked by an asterisk; ns: not significant

\begin{tabular}{|c|c|c|c|}
\hline \multirow[t]{2}{*}{ Expt } & \multicolumn{3}{|c|}{ VLP production or decay $\left(\times 10^{4} \mathrm{VLP} \mathrm{ml}^{-1} \mathrm{~h}^{-1}\right)$} \\
\hline & A & $\mathrm{B}$ & $\mathrm{C}$ \\
\hline 1-SW, unfiltered ${ }^{\mathrm{a}}$ & $-0.3^{*}(\mathrm{p}<0.06)$ & ns & ns \\
\hline 1-SW, filtered ${ }^{a}$ & ns & ns & ns \\
\hline 2-SW, unfiltered & ns & $20^{*}(\mathrm{p}<0.06)$ & $3.0(\mathrm{p}<0.03)$ \\
\hline 3-SW, unfiltered & $3.5^{*}(\mathrm{p}<0.06)$ & ns & ns \\
\hline 3-SW, filtered & ns & ns & ns \\
\hline 4-SW, unfiltered & ns & ns & ns \\
\hline 4-IST, unfiltered & $-1.6(\mathrm{p}<0.01)$ & ns & ns \\
\hline 5-SW, filtered ${ }^{\mathrm{b}}$ & $0.8(\mathrm{p}<0.05)$ & ns & ns \\
\hline 5-IST, unfiltered & $4.8^{*}(p=0.05)$ & $0.7(\mathrm{p}<0.02)$ & $2.5(\mathrm{p}<0.002)$ \\
\hline 5-IST, filtered & ns & ns & ns \\
\hline \multicolumn{4}{|c|}{$\begin{array}{l}\text { a Initial VLP concentrations could not be determined due to high } \\
\text { background fluorescence; regressions were calculated beginning at } \\
t=7.5 \mathrm{~h} \\
\text { bVLP production was not measurable in unfiltered bottles due to high } \\
\text { particle concentrations (see 'Results') }\end{array}$} \\
\hline
\end{tabular}

calculation. A similar calculation was not possible for Expt 5-SW, because the high particle load prevented VLP production measurements in unfiltered bottles. Using the range of average burst sizes determined in Expt 3-SW, or else 18.5 (the only other available field estimate of average burst size in the Arctic; Middelboe et al. 2002), virusinduced mortality inferred from mean VLP production rates varied between -0.005 and $-0.061 \mathrm{~h}^{-1}$ in unfiltered incubations (Table 4).

\section{DISCUSSION}

\section{General environmental features}

Despite the more oligotrophic conditions (as indicated by surface chl a concentrations), winter bottom-water concentrations of POC, PON and particles were similar to or greater than those measured in bottom waters of Franklin Bay and the Beaufort Shelf in (Fig. 2, Table 5), although weak evidence consistent with grazing (negative slopes) was found in Expts 1SW and 3-SW (Fig. 2A,B). The addition of yeast extract may have stimulated grazing in Expts 1-SW and (possibly) 5-IST (Fig. 2A,D, Table 5), but the resulting rates were again not statistically significant. Likewise, grazing rates estimated separately from flagellate abundance and an assumed clearance rate $\left(m_{\mathrm{g}}[\mathrm{cl}]\right.$ in Table 5) were low (-0.002 or $-0.003 \mathrm{~h}^{-1}$ ) and in reasonable agreement with our final approach to estimating grazing $\left(m_{\mathrm{g}}{ }^{*}=-0.002\right.$ or $\left.-0.004 \mathrm{~h}^{-1}\right)$. In contrast, significant increases in apparent growth rate with dilution in VLP-free seawater were detected in 2 of 3 such experiments (Expts 3-SW and 5-SW; Fig. 2B,C, Table 5). Since a significant slope due to grazing was not measured in these samples, the implied mortality rates of -0.008 and $-0.015 \mathrm{~h}^{-1}$ can be attributed solely to viruses. A second estimate of virusinduced mortality, $m_{\mathrm{v}}{ }^{*}$, based on a comparison of the intrinsic growth rates $\mu_{\mathrm{g}}$ and $\mu_{\mathrm{v}}$, determined qualitatively similar virus-induced mortality rates, i.e. virus-induced mortality was higher in Expt 3-SW $\left(-0.011 \mathrm{~h}^{-1}\right)$ than in Expt 5-SW $\left(-0.006 \mathrm{~h}^{-1}\right)$. The corresponding measurement of mean VLP production for Expt 3-SW enabled an estimate of average burst size, which was between 6.5 and 9, depending on whether $m_{\mathrm{v}}$ or $m_{\mathrm{v}}{ }^{*}$ was used for the
Table 4. Mean VLP production or decay $( \pm \mathrm{SE})$ for experiments in which rates were detectable, along with calculated turnover times and virus-induced mortality assuming burst sizes (BS) of $6.5,9$, or 18.5 . To calculate the average rate for each experiment, rates not significantly different from zero were taken to be zero. na: not applicable; nd: not determined

\begin{tabular}{|c|c|c|c|c|c|}
\hline \multirow[t]{2}{*}{ Expt } & \multirow{2}{*}{$\begin{array}{c}\text { Mean VLP production } \\
\text { or decay } \\
\left(\times 10^{4} \mathrm{VLP} \mathrm{ml}^{-1} \mathrm{~h}^{-1}\right)\end{array}$} & \multirow[t]{2}{*}{$\begin{array}{c}\text { Viral } \\
\text { turnover (d) }\end{array}$} & \multicolumn{3}{|c|}{$\begin{array}{l}\text { Virus-induced mortality }\left(\mathrm{h}^{-1}\right) \\
\text { for assumed BS: }\end{array}$} \\
\hline & & & 6.5 & 9 & 18.5 \\
\hline 1-SW & $-0.1 \pm 0.1$ & na & na & na & na \\
\hline 2-SW & $7.7 \pm 6.2$ & 0.9 & -0.061 & -0.044 & -0.021 \\
\hline 3-SW & $1.2 \pm 1.2$ & 11.8 & -0.015 & -0.011 & -0.005 \\
\hline 4-IST & $-0.5 \pm 0.5$ & na & na & na & na \\
\hline $5-\mathrm{SW}^{\mathrm{a}}$ & $0.3 \pm 0.3$ & nd & -0.002 & -0.001 & -0.0005 \\
\hline 5-IST & $2.7 \pm 1.2$ & 6.3 & -0.015 & -0.011 & -0.005 \\
\hline
\end{tabular}



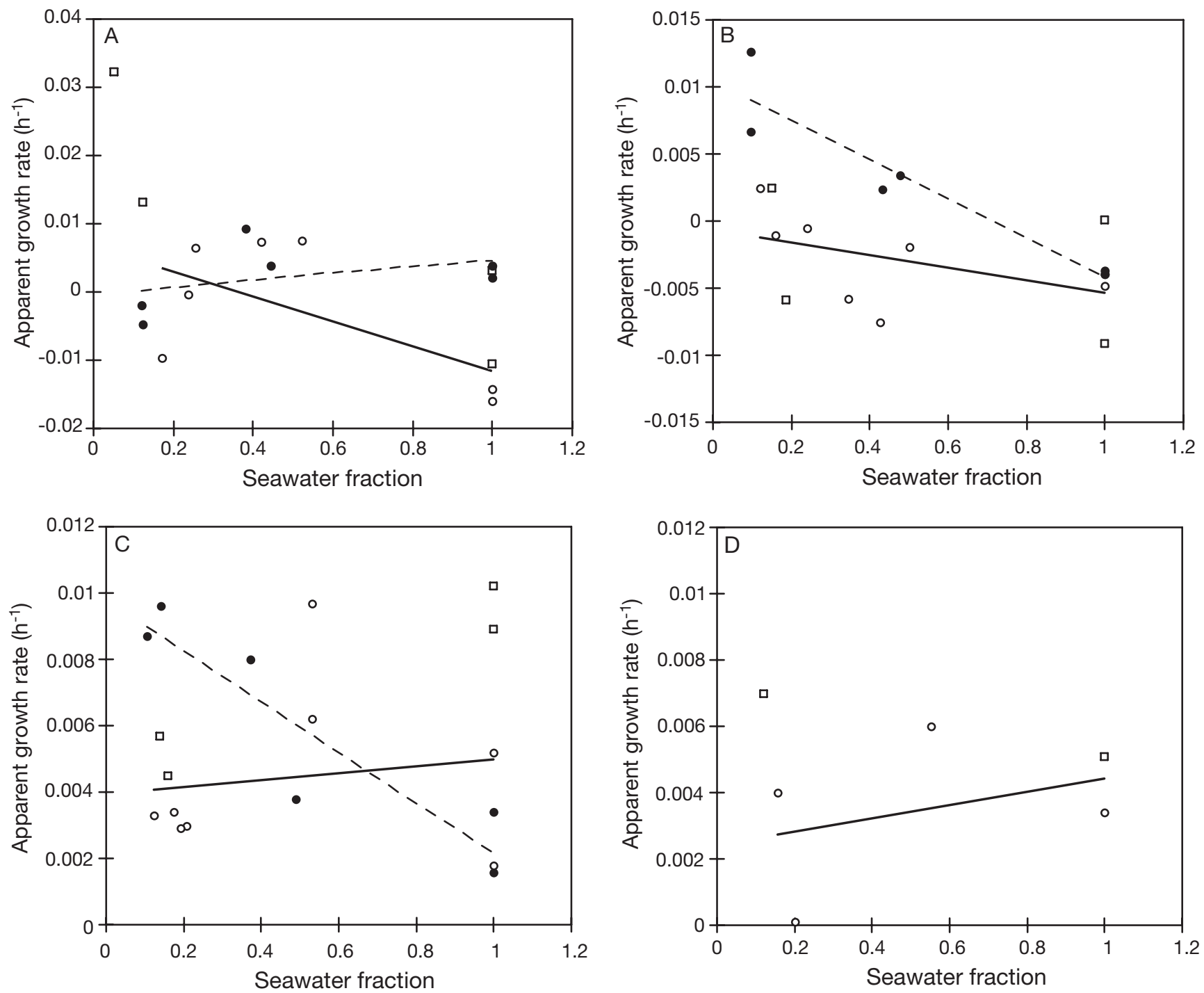

Fig. 2. Apparent bacterial growth rate plotted against the seawater fraction for grazing and virus-induced mortality in (A) Expt 1SW, (B) Expt 3-SW, (C) Expt 5-SW and (D) Expt 5-IST. Open symbols: unamended (O) or yeast-extract amended ( $\square$ ) grazing experiments; •: virus-induced mortality experiments (not attempted in Expt 5-IST, where volume restrictions prevented duplicate treatments). The significances of the slopes and $y$-intercepts of the linear regressions (bold lines: grazing; dashed lines: virus-induced mortality) are reported in Table 5

Winter concentrations of total bacteria in the bottom samples collected $\left(1.2\right.$ to $\left.3.0 \times 10^{5} \mathrm{ml}^{-1}\right)$ were comparable to those reported at similar depths in Franklin Bay during an oligotrophic period of the fall of 2000 (Wells \& Deming 2003) and about half those found in the less oligotrophic fall of 2002 (Wells et al. 2006). The positive correlation of bacterial abundance (sampled from the Moon Pool) with calendar day of the year suggests that the bacterial assemblages may have become more active as the sampling period progressed. Measurements of respiring bacteria early in the season, using the fluorogenic tetrazolium dye CTC after Huston \& Deming (2002), indicated low percentages (0.4 and
$1.3 \%$ of total bacteria for the pilot and Expt 1-SW, respectively), broadly consistent with the statistically insignificant Expt 1-SW growth rate (Table 5). While further CTC measurements were not possible, a more active bacterial community later in the season was implied by the determinable intrinsic bacterial growth rates $\left(\mu_{\mathrm{v}}=0.010 \mathrm{~h}^{-1}\right)$ of Expts 3-SW and 5-SW (Table 5). The measurable rates in these experiments may have also reflected use of a bottom-tripped Niskin, which enabled sampling closer to the seafloor (within 0.5 rather than $2 \mathrm{~m}$ ) and captured higher particle concentrations than the rosette (Table 2). Whether related to seasonal progression or greater concentrations of par- 
Table 5. Bacterial mortality attributed to grazing $\left(m_{\mathrm{g}}\right)$ or viruses $\left(m_{\mathrm{v}}\right)$ and corresponding bacterial growth rates $\left(\mu_{\mathrm{g}}\right.$ and $\left.\mu_{\mathrm{v}}\right)$ in $0.2 \mu \mathrm{m}$ filtered and VLP-free dilution experiments, with yeast-extract-amended experiments indicated (+ ye). Statistical significance ( $\mathrm{p}$-value) or $\mathrm{n}$ (where indicated) is in parentheses; $95 \%$ confidence intervals of significant results ( $\mathrm{p}<0.05$, in bold) are reported in footnotes. Parameter $m_{\mathrm{g}}[\mathrm{cl}]$ was estimated from flagellate abundance and assumed clearance rate; $m_{\mathrm{g}}{ }^{*}$ and $m_{\mathrm{v}}{ }^{*}$ were calculated as stated in 'Materials and methods'. Units are $\mathrm{h}^{-1}$; nd: not determined

\begin{tabular}{|c|c|c|c|c|c|c|c|c|}
\hline \multirow[t]{2}{*}{ Expt } & $0.2 \mu \mathrm{m}$ dilutions & \multicolumn{2}{|c|}{$0.2 \mu \mathrm{m}$ dilutions $+\mathrm{ye}$} & \multicolumn{2}{|c|}{ VLP-free dilutions } & \multirow{2}{*}{$m_{\mathrm{g}}[\mathrm{cl}]$} & \multirow[t]{2}{*}{$m_{\mathrm{v}}$} & \multirow{2}{*}{$m_{\mathrm{v}}{ }^{*}$} \\
\hline & $m_{\mathrm{g}}$ & $m_{\mathrm{g}}$ & $\mu_{g}$ & $m_{\mathrm{g}}+m_{\mathrm{v}}$ & $\mu_{\mathrm{v}}$ & & & \\
\hline 1-SW & $-0.018(0.14) \quad 0.007(0.35)$ & $-0.030(0.13)$ & $0.026(0.09)$ & $0.005(0.42)$ & $-0.0005(0.9)$ & -0.002 nd & nd & nd \\
\hline 3-SW & $-0.005(0.21)-0.0007(0.74)$ & $-0.004(0.68)$ & $-0.001(0.87)$ & $-\mathbf{0 . 0 1 5 ^ { \mathrm { a } } ( 0 . 0 0 5 )}$ & $0.010^{\mathrm{a}}(0.003)$ & $-0.002-0.004$ & -0.015 & -0.011 \\
\hline $5-\mathrm{SW}$ & $0.001(0.73) \quad 0.004(0.052)$ & $\mathbf{0 . 0 0 5}^{\mathrm{b}}(0.04)$ & $\mathbf{0 . 0 0 4}^{\mathrm{b}}(0.03)$ & $-\mathbf{0 . 0 0 8}^{\mathrm{c}}(0.01)$ & $\mathbf{0 . 0 1 0}^{\mathrm{c}}(0.0008)$ & $-0.003-0.002$ & -0.009 & -0.006 \\
\hline 5-IST & $0.002(0.68) \quad 0.002(0.43)$ & $-0.002(\mathrm{n}=2)$ & $0.007(\mathrm{n}=2)$ & nd & nd & -0.003 nd & $\mathrm{nd}^{\mathrm{d}}$ & nd \\
\hline \multicolumn{9}{|c|}{$\begin{array}{l}{ }^{\mathrm{a}} m_{\mathrm{g}}+m_{\mathrm{v}}:-0.022 \text { to }-0.008 ; \mu_{\mathrm{v}}: 0.006 \text { to } 0.015 \\
{ }^{\mathrm{b}} m_{\mathrm{g}}: 0.0005 \text { to } 0.001 ; \mu_{\mathrm{g}}: 0.001 \text { to } 0.008 \\
{ }^{\mathrm{c}} m_{\mathrm{g}}+m_{\mathrm{v}}:-0.012 \text { to }-0.003 ; \mu_{\mathrm{v}}: 0.007 \text { to } 0.013 \\
{ }^{\mathrm{d}} \text { Virus-induced mortality calculated from VLP }\end{array}$} \\
\hline
\end{tabular}

ticles (or both), the rates measured in Expts 3-SW and 5-SW were within the range of those from Resolute Bay (0.003 to $0.030 \mathrm{~h}^{-1}$; Anderson \& Rivkin 2001), the only other available winter-time Arctic measurements (albeit in surface waters), as well as spring- and summer-time measurements made in surface waters there $\left(0.006\right.$ to $\left.0.043 \mathrm{~h}^{-1}\right)$ and in the North Water $(0.005$ to $0.016 \mathrm{~h}^{-1}$; Middelboe et al. 2002).

Winter bottom-water VLP concentrations of 1.4 to $3.3 \times 10^{6} \mathrm{ml}^{-1}$ were similar to summer concentrations at comparable Arctic depths elsewhere $\left(<1\right.$ to $7 \times 10^{6}$ $\mathrm{ml}^{-1}$; Steward et al. 1996), including some near-bottom depths. They were greater, however, than the few available measurements from surface waters during Arctic or Antarctic winter $\left(0.6\right.$ to $4.9 \times 10^{5} \mathrm{ml}^{-1}$; Bergh et al. 1989, Smith et al. 1992), instead resembling more closely those observed in various Arctic surface waters during spring $\left(<1\right.$ to $4 \times 10^{6} \mathrm{ml}^{-1}$; Maranger et al. 1994, Yager et al. 2001) and summer (1.4 to $36 \times 10^{6} \mathrm{ml}^{-1}$; Steward et al. 1996, Yager et al. 2001, Middelboe et al. 2002). The median VBR of 14 (10 if IST are excluded) likewise was similar to the VBR reported from other Arctic waters ( 11, as implied by Fig. 6 in Steward et al. 1996), especially during algal blooms (10 to 32; Maranger et al. 1994, Yager et al. 2001). Pre- or postbloom values reported for the Arctic have typically been lower ( 5; Yager et al. 2001, Middelboe et al. 2002). In the present study, correlations of VLP with POC and particle concentrations in bottom samples suggested the importance of particles to VLP dynamics in Arctic winter, as observed in previous Arctic work during summer (Hodges et al. 2005) and in other estuaries (Hewson et al. 2001). We note that the recent demonstration that virus abundance can decline significantly in formaldehyde-fixed samples (Wen et al. 2004) suggests that these viral counts should be considered underestimates.

\section{Ecological importance of grazers and viruses}

Unlike Anderson \& Rivkin (2001), who examined winter surface waters, we did not find strong evidence for winter-time bacterivory in our bottom-water samples using the dilution method. None of our unamended experiments yielded a slope significantly different from zero (Table 5, Fig. 2), nor did addition of yeast extract have a significant stimulatory effect (Table 5). Use of the same techniques and equipment on this expedition yielded significant grazing rates in the overlying sea ice (Wells 2006), arguing against methodological issues accounting for insignificant grazing rates in bottom waters. The lack of detectable grazing in this study is more likely due to the relatively low concentrations of bacteria and meager flagellate numbers, possibly implying threshold effects that have only rarely been supported by field measurements (Lessard \& Murrell 1998). Alternatively, grazing rates (and changes in apparent bacterial growth rate) may have been too low to measure reliably with a microscopy-based dilution approach. Grazing rates of -0.002 to $-0.004 \mathrm{~h}^{-1}$ implied by other methods (flagellate abundance and assumed clearance rate, or $m_{\mathrm{g}}{ }^{*}$ ) were modest at best and lower than the smallest value $\left(-0.006 \mathrm{~h}^{-1}\right)$ reported by Anderson \& Rivkin (2001). For bacterial growth rates of $0.010 \mathrm{~h}^{-1}$ (as measured in Expts 3-SW and 5-SW), Anderson and Rivkin's regression of grazing rate against bacterial growth rate also implies a grazing rate of $-0.004 \mathrm{~h}^{-1}$.

Unlike grazing, bacterial mortality attributable to viruses was readily detected in 2 of 3 experiments using the dilution approach (Table 5, Fig. 2B,C). Samples taken for DOC analysis to rule out artifactual enrichment from the UF were unfortunately lost during transport, but 2 facts argue against this possibility. First, no stimulation of bacterial growth was evident in UF dilu- 
tions compared to $0.2 \mu \mathrm{m}$ dilutions of Expt 1-SW, even though addition of yeast extract in this experiment did appear to stimulate bacterial growth (Fig. 2A). Second, in contrast to Expt 1-SW, bacterial growth in the most diluted $0.2 \mu \mathrm{m}$ treatments of Expts 3-SW and 5-SW was not enhanced by added yeast extract (Fig. 2B,C), even though such addition would presumably have mimicked an artifactual enrichment from the UF. Instead, the data from our dilution experiments (including the alternative grazing rates mentioned above) indicate that, when detectable, mortality due to viruses was at least twice that due to grazers and accounted for 73 to $100 \%$ (Expt 3-SW) or 63 to $100 \%$ (Expt 5-SW) of the measured bacterial mortality (Table 5), equivalent to $0.6-1.5 \%$ of the bacterial population per hour. Similar observations of viruses equaling or surpassing grazers as agents of bacterial mortality have been reported for the Arctic (mostly at the surface, but also in some deeper waters, including near the bottom; Steward et al. 1996) and the Antarctic (at all stations where comparison was possible; Guixa-Boixereu et al. 2002), though in these 2 cases grazing (in the Arctic) or virus-induced mortality (in the Antarctic) was inferred indirectly (from flagellate abundance or viral decay rate, respectively). Virusinduced mortality exceeding grazing has also been reported at high salinities in solar salterns (Guixa-Boixereu et al. 1996), in the metalimnion and hypolimnion of Lake Plußsee (Weinbauer \& Hofle 1998) and periodically during a coastal, mesocosm algal bloom (GuixaBoixereu et al. 1999). Together with the low flagellate numbers, this greater contribution of viruses than grazers to bacterial mortality in our study suggests increased cycling of bacteria-derived organic matter within the bacterial pool before or instead of transfer to higher trophic levels. Another implication of our virusinduced mortality results is that standard $(0.2 \mu \mathrm{m}$ filtered) dilution experiments may substantially underestimate true bacterial growth rates (Table 5).

In comparison to VLP production rates in more temperate waters (e.g. $10^{5}$ to $10^{6} \mathrm{VLP} \mathrm{ml}^{-1} \mathrm{~h}^{-1}$; see Table 4 in Mei \& Danovaro 2004), mean rates measured in Franklin Bay were low $\left(0.3\right.$ to $\left.7.7 \times 10^{4} \mathrm{VLP} \mathrm{ml}^{-1} \mathrm{~h}^{-1}\right)$, undetectable, or negative (indicating net decay; Table 4). Comparably low or nearly identical ranges of production rate have previously been reported for Arctic waters $\left(0.3\right.$ to $7.3 \times 10^{4} \mathrm{VLP} \mathrm{ml}^{-1} \mathrm{~h}^{-1}$ in the North Water by Middelboe et al. 2002 and 0.08 to $58 \times 10^{4}$ VLP ml ${ }^{-1} \mathrm{~h}^{-1}$ in the Bering and Chukchi Seas by Steward et al. 1996) or under simulated winter sea-ice conditions (up to $1.8 \times 10^{4} \mathrm{VLP} \mathrm{ml}^{-1} \mathrm{~h}^{-1}$; Wells \& Deming 2006). In general, detectable VLP production in at least 1 replicate of Expts 3-SW and 5-SW (filtered) supported the corresponding measurement of virusinduced mortality, while the net VLP decay measured in Expt 1-SW accorded with undetectable virus- induced mortality in that experiment. In all 3 cases, however, the mean production or decay rates were not significantly different from zero (Table 4), reflecting the high variability among replicates. The cause of the variability observed among replicates is unknown, but could include a heterogeneous distribution of active bacteria (especially particle associated), the effects of which would likely be accentuated as the sensitivity limits of a method were approached. Overall sensitivity may also have been affected by small average burst sizes, as calculated for Expt 3-SW and seen under oligotrophic conditions in other work (e.g. burst sizes of 4 to 6 for starved cells in river water; Kokjohn et al. 1991). As shown in Table 4, low burst sizes imply greater virus-induced mortality than would be inferred using traditionally assumed burst sizes of 18.5 (for the Arctic; Middelboe et al. 2002) or 30 (Weinbauer et al. 2002). We caution, however, that the variability in our measurements of VLP production implies considerable uncertainty in the calculated burst size of Expt 3-SW, as well as (in most cases) of virus-induced mortality inferred from VLP production (Table 4).

Regarding trap samples, although no VLP production was detected in the first one (Expt 4-IST), the significant VLP production observed in all 3 replicates of the more particle- and POC-rich second sample (Expt 5-IST; Table 3, Fig. 1B) supports a prior report of visibly infected bacteria associated with sinking particles in warmer waters (Proctor \& Fuhrman 1991). The concordance of the 3 replicates also enabled a robust estimate of virus-induced mortality between -0.005 and $-0.015 \mathrm{~h}^{-1}$ (depending on the assumed burst size; Table 4), again indicating that, as in the water column, bacterial losses due to viruses in a particle-rich sediment trap were comparable to or greater than those due to grazing (undetected in the dilution experiment [Fig. 2D] and $-0.003 \mathrm{~h}^{-1}$ as calculated from flagellate abundance).

Because of evidence that PAB can be disproportionately responsible for bacterial production or activity (e.g. Crump et al. 1998), including during winter (Griffith et al. 1994) and in the Arctic (Yager et al. 2001, Huston \& Deming 2002, Junge et al. 2004, Garneau et al. 2006), we considered that PAB might also disproportionately produce viruses. The literature provides some support for this hypothesis in the form of higher VLP production rates in unfiltered than filtered seawater (Steward et al. 1992, Šimek et al. 2001), including in polar waters (see Fig. 5B in Guixa-Boixereu et al. 2002), though whether the higher rates were due to grazing effects, the contributions of $\mathrm{PAB}$, or both is unclear. Similarly, several studies concluding that lysogeny was insignificant in specific marine environments (Wilcox \& Fuhrman 1994, Weinbauer \& Suttle 1996, 1999) have in common prefiltration of samples 


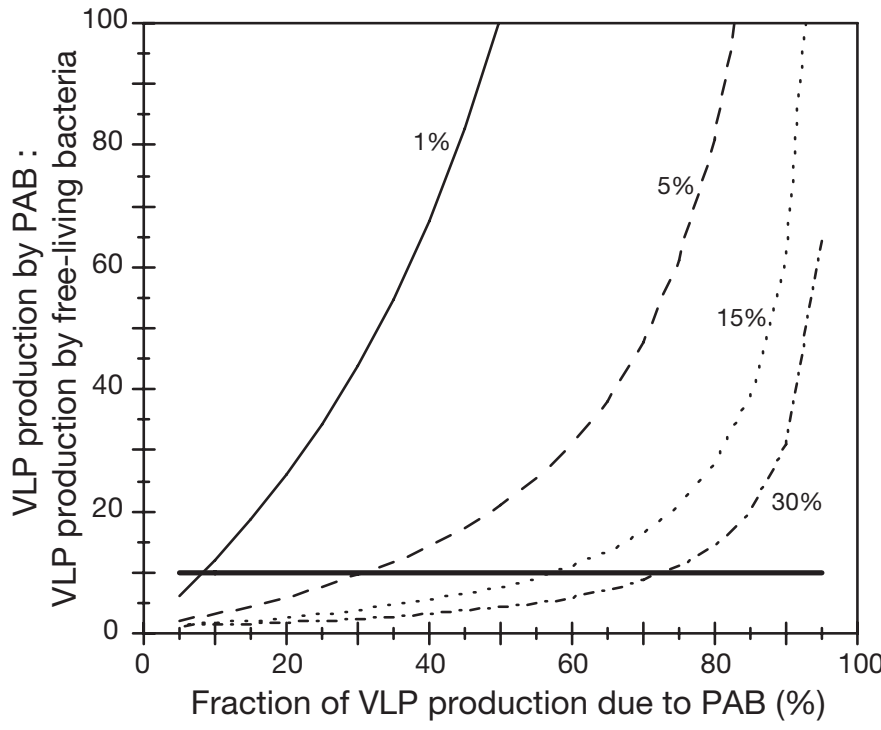

Fig. 3. Theoretical relationship between relative rates (ratios) of virus-like particle (VLP) production by particle-associated bacteria $(\mathrm{PAB})$ and free-living bacteria and the fraction of total VLP production due to PAB, for bacterial communities composed of $1,5,15$, or $30 \%$ PAB. The horizontal line indicates a 10 -fold greater virus production rate by $\mathrm{PAB}$ than freeliving bacteria. The calculation is based on the equation: total virus production $=($ virus production by free-living bacteria $\times$ fraction of free-living bacteria) + (virus production by $\mathrm{PAB} \times$ fraction of $\mathrm{PAB}$ )

through GF/F, 1.0 or $1.2 \mu \mathrm{m}$, meshes likely to exclude both grazers and PAB. We attempted to test this hypothesis by comparing VLP production rates in unfiltered and filtered seawater, but the overall low rates and the variability associated with individual replicates prevented resolution of the issue. Nevertheless, our data provide 2 lines of evidence consistent with this hypothesis. First, in the most particle-rich trap sample (Expt 5-IST), significant VLP production was measured in all 3 unfiltered replicates, but not in the filtered bottles (Table 3). Because grazing rates were low or undetectable (Table 5), much of the difference can reasonably be attributed to $\mathrm{PAB}$, which represented a large fraction (10\%) of the bacteria. Second, significant (but very low) VLP production was determined in only 1 of 12 filtered bottom-water incubations, compared with 6 of 18 unfiltered ones (Table 3). Unfortunately, in that 1 filtered incubation, direct comparison with unfiltered treatments was not possible due to high particle loads.

Even if we had been able to measure small differences between unfiltered and filtered treatments in these low-activity samples, it is unlikely that the results would have been conclusive with regards to the role of PAB in VLP production. As shown in Fig. 3, PAB could produce viruses at a rate an order of magnitude greater than the free-living assemblage, yet contribute only a small fraction to the total measured VLP production (e.g. 8 to $30 \%$ if the PAB fraction is 1 to $5 \%$ ). More sensitive techniques are likely required to delineate the relative contributions of $\mathrm{PAB}$ and free-living bacteria to VLP production, at least under conditions of low microbial activity.

\section{CONCLUSIONS}

Despite low chl a concentrations in the overlying icecovered waters, the microbial ecosystem in winter bottom waters of Franklin Bay was at times dynamic. When detectable, apparent bacterial growth rates were comparable to those in Arctic surface waters of other seasons and locales. Correlations of VLP and the percentage of PAB to POC, and detection (by dilution experiments) of virus-induced mortality and bacterial growth only in the most particle-rich samples, pointed to the importance of particles to this ecosystem, perhaps in part as an organic carbon source. Along with the prevailing oligotrophic conditions of the study period, the high fraction of mortality due to viruses (67 to $100 \%$ ) corresponds to the conditions under which the viral short circuit is predicted to have maximal effect on carbon transfer to higher trophic levels (Murray \& Eldridge 1994). Viral lysis, especially under oligotrophic conditions, could also provide a significant (though small) source of labile organic material helping to sustain other bacteria through the winter, such that the observed near-balance between virus-induced mortality $\left(m_{\mathrm{v}}\right.$ or $\left.m_{\mathrm{v}}{ }^{*}\right)$ and bacterial growth rates was not fortuitous.

Acknowledgements. This research was funded by NSF awards (OPP-0327244 and IGERT through DGE-9870713) and a NASA-ABI award (NCC 2-1273) and is a contribution to the international Canadian Arctic Shelf Exchange Study (CASES). We thank S. Demers (University of Quebec at Rimouski) for chl a data, C. Michel and B. LeBlanc (Department of Fisheries and Oceans, Freshwater Institute, Winnipeg, Manitoba, Canada) for IST use, M. Zajaczkowski and W. Walkusz (Department of Marine Ecology, Institute of Oceanology, Polish Academy of Sciences, Sopot, Poland) for IST deployment, T. Businski (Memorial University of Newfoundland, St. John's, Newfoundland, Canada) for help with sample collections, S. Carpenter for shipboard and laboratory assistance, and R. Sirius, S. Redding and D. Moore for general support.

\section{LITERATURE CITED}

Anderson MR, Rivkin RB (2001) Seasonal patterns in grazing mortality of bacterioplankton in polar oceans: a bipolar comparison. Aquat Microb Ecol 25:195-206

Bergh O, Borsheim KY, Bratbak G, Heldal M (1989) High abundance of viruses found in aquatic environments. Nature 340:467-468 
Cochlan WP, Wikner J, Steward GF, Smith DC, Azam F (1993) Spatial distribution of viruses, bacteria and chlorophyll $a$ in neritic, oceanic and estuarine environments. Mar Ecol Prog Ser 92:77-87

Cotner JB, Johengen TH, Biddanda BA (2000) Intense winter heterotrophic production stimulated by benthic resuspension. Limnol Oceanogr 45:1672-1676

Crump BC, Baross JA, Simenstad CA (1998) Dominance of particle-attached bacteria in the Columbia River estuary, USA. Aquat Microb Ecol 14:7-18

Daniel C, Gutseit K, Anesio AM, Graneli W (2005) Microbial food webs in the dark: independence of lake plankton from recent algal production. Aquat Microb Ecol 38: 113-123

Edlin G, Lin L, Bitner R (1977) Reproductive fitness of P1, P2 and $\mathrm{Mu}$ lysogens of E. coli. J Virol 21:560-564

Eissler Y, Sahlsten E, Quiñones RA (2003) Effects of virus infection on respiration rates of marine phytoplankton and microplankton communities. Mar Ecol Prog Ser 262:71-80

Evans C, Archer SD, Jacquet S, Wilson WH (2003) Direct estimates of the contribution of viral lysis and microzooplankton grazing to the decline of a Micromonas spp. population. Aquat Microb Ecol 30:207-219

Fuhrman JA, Noble RT (1995) Viruses and protists cause similar bacterial mortality in coastal seawater. Limnol Oceanogr 40:1236-1242

Fuhrman JA, Suttle CA (1993) Viruses in marine planktonic systems. Oceanography 6:51-63

Garneau ME, Vincent WF, Alonso-Sáez L, Gratton Y, Lovejoy C (2006) Prokaryotic community structure and heterotrophic production in a river-influenced coastal arctic ecosystem. Aquat Microb Ecol 42:27-40

Gobler CJ, Hutchins DA, Fisher NS, Cosper EM, SanudoWilhelmy SA (1997) Release and bioavailability of C, N, P, Se and Fe following viral lysis of a marine chrysophyte. Limnol Oceanogr 42:1492-1504

Griffith P, Shiah FK, Gloersen K, Ducklow HW, Fletcher M (1994) Activity and distribution of attached bacteria in Chesapeake Bay. Mar Ecol Prog Ser 108:1-10

Griffiths RP, Hayasaka SS, McNamara TM, Morita RY (1978) Relative microbial activity and bacterial concentrations in water and sediment samples taken in the Beaufort Sea. Can J Microbiol 24:1217-1226

Guixa-Boixereu N, Calderon-Paz JI, Heldal M, Bratbak G, Pedros-Alio C (1996) Viral lysis and bacterivory as prokaryotic loss factors along a salinity gradient. Aquat Microb Ecol 11:215-227

Guixa-Boixereu N, Lysnes K, Pedros-Alio C (1999) Viral lysis and bacterivory during a phytoplankton bloom in a coastal water microcosm. Appl Environ Microbiol 65:1949-1958

Guixa-Boixereu N, Vaque D, Gasol JM, Sanchez-Camara J, Pedros-Alio C (2002) Viral distribution and activity in Antarctic waters. Deep-Sea Res II 49:827-845

Hara S, Koike I, Terauchi K, Kamiya H, Tanoue E (1996) Abundance of viruses in deep oceanic waters. Mar Ecol Prog Ser 145:269-277

Helmke E, Weyland H (1995) Bacteria in sea ice and underlying water of the eastern Weddell Sea in midwinter. Mar Ecol Prog Ser 117:269-287

Hewson I, O'Neil JM, Fuhrman JA, Dennison WC (2001) Virus-like particle distribution and abundance in sediments and overlying waters along eutrophication gradients in two subtropical estuaries. Limnol Oceanogr 46: $1734-1746$

Hodges LR, Bano N, Hollibaugh JT, Yager PT (2005) Illustrating the importance of particulate organic matter to pelagic microbial abundance and community structure - an Arc- tic case study. Aquat Microb Ecol 40:217-227

Huston AL, Deming JW (2002) Relationship between microbial extracellular enzymatic activity and suspended and sinking particulate organic matter: seasonal transformations in the North Water. Deep-Sea Res II 49:5211-5225

Junge K, Eicken H, Deming JW (2004) Bacterial activity at -2 to $-20^{\circ} \mathrm{C}$ in Arctic wintertime sea ice. Appl Environ Microbiol 70:550-557

Kokjohn TA, Sayler GS, Miller RV (1991) Attachment and replication of Pseudomonas aeruginosa bacteriophages under conditions simulating aquatic environments. J Gen Microbiol 137:661-666

Landry MR, Hassett RP (1982) Estimating the grazing impact of marine micro-zooplankton. Mar Biol 67:283-288

Lessard EJ, Murrell MC (1998) Microzooplankton herbivory and phytoplankton growth in the northwestern Sargasso Sea. Aquat Microb Ecol 16:173-188

Levinsen H, Nielsen TG (2002) The trophic role of marine pelagic ciliates and heterotrophic dinoflagellates in arctic and temperate coastal ecosystems: a cross-latitude comparison. Limnol Oceanogr 47:427-439

Lin L, Bitner R, Edlin G (1977) Increased reproductive fitness of Escherichia coli Lambda lysogens. J Virol 21:554-559

Maranger R, Bird DF, Juniper SK (1994) Viral and bacterial dynamics in Arctic sea ice during the spring algal bloom near Resolute, N.W.T., Canada. Mar Ecol Prog Ser 111: 121-127

Mei ML, Danovaro R (2004) Virus production and life strategies in aquatic sediments. Limnol Oceanogr 49:459-470

Melnikov IA, Kolosova EG, Welch HE, Zhitina LS (2002) Sea ice biological communities and nutrient dynamics in the Canada Basin of the Arctic Ocean. Deep-Sea Res I 49: 1623-1649

Middelboe M, Jorgensen NOG, Kroer N (1996) Effects of viruses on nutrient turnover and growth efficiency of noninfected marine bacterioplankton. Appl Environ Microbiol 62:1991-1997

Middelboe M, Nielsen TG, Bjornsen PK (2002) Viral and bacterial production in the North Water: in situ measurements, batch-culture experiments and characterization and distribution of a virus-host system. Deep-Sea Res II 49:5063-5079

Middelboe M, Riemann L, Steward GF, Hansen V, Nybroe O (2003) Virus-induced transfer of organic carbon between marine bacteria in a model community. Aquat Microb Ecol 33:1-10

Murray AG, Eldridge PM (1994) Marine viral ecology: incorporation of bacteriophage into the microbial planktonic food web paradigm. J Plankton Res 16:627-641

Murray AG, Jackson GA (1992) Viral dynamics: a model of the effects of size, shape, motion and abundance of singlecelled planktonic organisms and other particles. Mar Ecol Prog Ser 89:103-116

Noble RT, Fuhrman JA (1998) Use of SYBR Green I for rapid epifluorescence counts of marine viruses and bacteria. Aquat Microb Ecol 14:113-118

Noble RT, Fuhrman JA (1999) Breakdown and microbial uptake of marine viruses and other lysis products. Aquat Microb Ecol 20:1-11

Proctor LM, Fuhrman JA (1991) Role of viral infection in organic particle flux. Mar Ecol Prog Ser 69:133-142

Rysgaard S, Nielsen TG, Hansen BW (1999) Seasonal variation in nutrients, pelagic primary production and grazing in a high-Arctic coastal marine ecosystem, Young Sound, Northeast Greenland. Mar Ecol Prog Ser 179:13-25

Šimek K, Pernthaler J, Weinbauer MG, Hornak K, Dolan JR, Nedoma J, Masin M, Amann R (2001) Changes in bacter- 
ial community composition and dynamics and viral mortality rates associated with enhanced flagellate grazing in a mesoeutrophic reservoir. Appl Environ Microbiol 67: 2723-2733

Smith DC, Steward GF, Azam F (1992) Virus and bacteria abundance in the Drake Passage during January and August 1991. Antarct J US 27:125-127

Steward GF, Wikner J, Cochlan WP, Smith DC, Azam F (1992) Estimation of virus production in the sea. II. Field results. Mar Microb Food Webs 6:79-90

Steward GF, Smith DC, Azam F (1996) Abundance and production of bacteria and viruses in the Bering and Chukchi Seas. Mar Ecol Prog Ser 131:287-300

Tien G, Burgett J, Dore J, Geren M and 6 others (1992) Seasonal variability in microbial biomass in the Gerlache Strait: a feast-or-famine existence. Antarct J US 27: 166-167

Tremaine SC, Mills AL (1987) Tests of the critical assumptions of the dilution method for estimating bacterivory by microeukaryotes. Appl Environ Microbiol 53:2914-2921

Weinbauer MG, Hofle MG (1998) Significance of viral lysis and flagellate grazing as factors controlling bacterioplankton production in a eutrophic lake. Appl Environ Microbiol 64:431-438

Weinbauer MG, Peduzzi P (1995) Significance of viruses versus heterotrophic nanoflagellates for controlling bacterial abundance in the northern Adriatic Sea. J Plankton Res 17:1851-1856

Weinbauer MG, Suttle CA (1996) Potential significance of lysogeny to bacteriophage production and bacterial mortality in coastal waters of the Gulf of Mexico. Appl Environ Microbiol 62:4374-4380

Weinbauer MG, Suttle CA (1999) Lysogeny and prophage induction in coastal and offshore bacterial communities. Aquat Microb Ecol 18:217-225

Weinbauer MG, Winter C, Hofle MG (2002) Reconsidering transmission electron microscopy based estimates of viral infection of bacterioplankton using conversion

Editorial responsibility: Jed Fuhrman,

Los Angeles, California, USA factors derived from natural communities. Aquat Microb Ecol 27:103-110

Weinbauer MG, Brettar I, Hofle MG (2003) Lysogeny and virus-induced mortality of bacterioplankton in surface, deep and anoxic marine waters. Limnol Oceanogr 48: $1457-1465$

Wells LE (2006) Viral adaptations to life in the cold. PhD dissertation, University of Washington, Seattle, WA

Wells LE, Deming JW (2003) Abundance of Bacteria, the Cytophaga-Flavobacterium cluster and Archaea in cold oligotrophic waters and nepheloid layers of the Northwest Passage, Canadian Archipelago. Aquat Microb Ecol 31:19-31

Wells LE, Deming JW (2006) Modelled and measured dynamics of viruses in Arctic winter sea-ice brines. Environ Microbiol 8:1115-1121

Wells LE, Cordray M, Bowerman S, Miller L, Vincent WF, Deming JW (2006) Archaea in particle-rich waters of the Beaufort Shelf and Franklin Bay, Canadian Arctic: Clues to an allochthonous origin? Limnol Oceanogr 51:47-59

Wen K, Ortmann AC, Suttle CA (2004) Accurate estimation of viral abundance by epifluorescence microscopy. Appl Environ Microbiol 70:3862-3867

Wilcox RM, Fuhrman JA (1994) Bacterial viruses in coastal seawater: lytic rather than lysogenic production. Mar Ecol Prog Ser 114:35-45

Wilhelm SW, Brigden SM, Suttle CA (2002) A dilution technique for the direct measurement of viral production: a comparison in stratified and tidally mixed coastal waters. Microb Ecol 43:168-173

Wommack KE, Colwell RR (2000) Virioplankton: viruses in aquatic ecosystems. Microbiol Mol Biol Rev 64:69-114

Wommack KE, Ravel J, Hill RT, Colwell RR (1999) Hybridization analysis of Chesapeake Bay virioplankton. Appl Environ Microbiol 65:241-250

Yager PL, Connelly TL, Mortazavi B, Wommack KE, Bano N, Bauer JE, Opsahl S, Hollibaugh JT (2001) Dynamic bacterial and viral response to an algal bloom at subzero temperatures. Limnol Oceanogr 46:790-801

Submitted: November 15, 2005; Accepted: April 18, 2006 Proofs received from author(s): June 24, 2006 